\title{
Transforming Domestic Space: Arapoğlu Mansion, a Single-family House in Pera
}

\author{
Konut Mekanında Değişim ve Beyoğlu'nun Tek Aile Konutları: \\ Arapoğlu Evi Örnĕgi
}

\section{Burcu Selcen COŞKUN * Ceren LORDOĞLU **}

\begin{abstract}
Throughout $19^{\text {th }}$ century the Ottoman Empire witnessed significant economic, social and political transformations. The capital city of Istanbul, with a demographically diverse population had its own share of these changes. By the $19^{\text {th }}$ century, Pera, which had gradually begun to be built up from the middle of the $18^{\text {th }}$ century onwards became Istanbul's most cosmopolitan quarter, resembling the western presence in the city. It became a place for the elitist life of foreigners, the notables of the embassies and the non-Muslim minority groups. Around this period a new dwelling type emerged and began to be widely used. These were two to four storey structures, built on narrow frontage lots, each housing only one family. Located on populated roads, these houses didn't offer much outer space. The families moving into these houses probably had to abandon some of their existing living habits to adopt themselves to this new housing type. The Arapoğlu Mansion in Pera was one of these single family houses. It is one of the few buildings in Pera of this typology, which has managed to survive to the present day. After being used as a family residence, it was transformed into a multi-family residential building, and later, into various workshops. This paper aims to introduce the Arapoğlu Mansion as an example to develop an understanding of this typology and to evaluate the domestic life from an architectural perspective, which was formed through the change in lifestyles in the $19^{\text {th }}$ century. Survey drawings of the building, together with written documents describing domestic life in $19^{\text {th }}$ century were employed to investigate how space and social mutually might have affected each other, and, if space actually had an impact in the transforming of social life.
\end{abstract}

Keywords: Pera, Single-Family House, Arapoğlu Mansion, Domestic Space, Social Transformation

$\ddot{O}_{z}$ : Osmanlı İmparatorluğu, 19. yüzyıl'da önemli siyasal, ekonomik ve sosyal değişimlere sahne olmuş; çeşitli etnik grupları barındıran başkent İstanbul da bu değişimlerden payına düşeni almıştır. 18. yüzyıldan başlayarak Istanbul'un Batı'ya dönük yüzünü temsil eden Pera, şehrin en kozmopolit, yabancılara, elçilik mensuplarına ve gayrimüslimlere seçkin yaşam öğeleri sunan bir semt haline gelmeye başlar. Bu dönemde görülmeye başlayan, dar parseller üzerinde bitişik nizam kurgularla yükselen 2-4 katlı tek aile evleri, kentte varolan konut tiplerine bir yenilik getirir. Sıkışık yerleşimlerde konumlanan, sınırlı açık alana sahip bu yapılara geçmiş alışkanlıklarını terk ederek taşınan kullanıcıların yeni bir yaşam tarzına adapte olmaya çalıştıkları düşünülebilinir. Bu makale bu yeni konut tipine örnek oluşturan, günümüze dek ayakta kalmayı başaran az sayıdaki yapıdan biri olan Arapoğlu Evi örneği ekseninde bu tipolojiyi tanıtmayı ve 19. yüzyılın değişen yaşam tarzında şekillenen konut yaşamını mimari açıdan yorumlamayı hedeflemektedir. Çalışmada Arapoğlu Evi'nin mimari çizimleri ve dönemle ilgili ev hayatını tasvir eden yazılı belgelere başvurulacaktır. Böylece, sosyal değişimlerin mekan üzerindeki etkileri ve mekanın sosyal yaşamı dönüştürmesindeki itici gücü irdelenmeye çalışılacaktır.

Anahtar sözcükler: Pera, Tek-Aile Konutu, Arapoğlu Evi, Evsel Mekan, Sosyal Değişim

* Assoc. Prof. Dr., Architect, Mimar Sinan Fine Arts University, Department of Architecture, İstanbul. selcen.coskun@msgsu.edu.tr, https://orcid.org/0000-0002-9490-6393

** Ph.D, Sociologist, Mimar Sinan Fine Arts University, Women's Studies Research Center, İstanbul. ceren.lordoglu@msgsu.edu.tr, https://orcid.org/0000-0002-2709-7661 


\section{Introduction}

Ottoman capital, Istanbul experienced significant transformations in political, economical and social sphere during $19^{\text {th }}$ century, which had reflections on the urban form of the city. The two documents which aimed to bring the Empire closer to Europe were the Anglo-Turkish Commercial Treaty (1838) and the Tanzimat Edict (1839). The Commercial Treaty, the initial agreement of a series of other economical treaties with foreign countries, opened the way to Europeans to sell their products easily in the market, while the Edict demanded a policy of change and introduced the rule of law and equality over many subjects (Çelik 1986; Enlil 1999).

In those years there used to be three centres in the city where the population and urban functions were mostly gathered together, historical peninsula, Galata-Pera and Kadıköy (Tümertekin 2014, 15). Out of these three areas, Pera (Fig. 1), symbolized the European presence in Istanbul: an 'exotic' nonMuslim environment in the Empire. Pera housed the

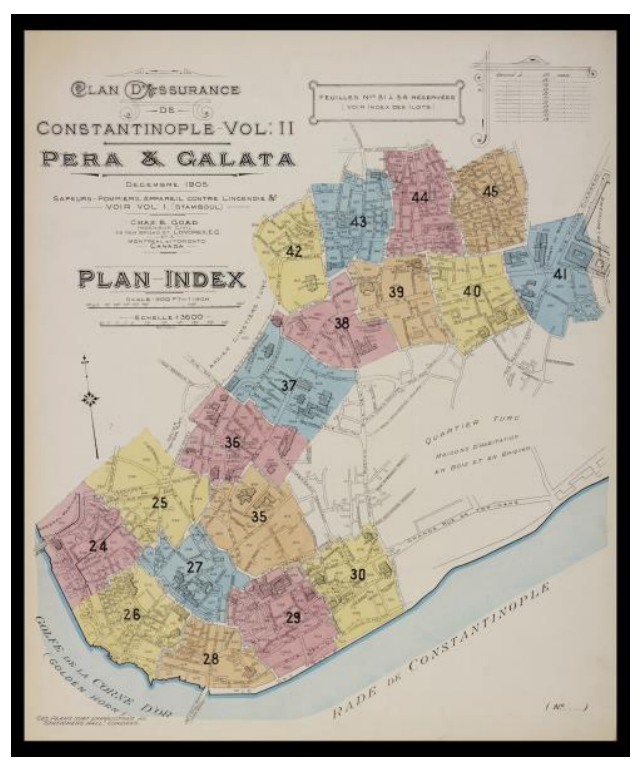

Fig. 1. The location of Galata and Pera in 1905 Goad maps (L'Institut Français d'Études Anatoliennes in Istanbul functions related with trade with foreign countries. After the treaty was ratified in 1838, Europeans started moving to Istanbul to get advantage of the economic benefits granted to tradesmen. Galata and Pera became the most cosmopolitan quarter of the city. New buildings with multi storeys started to appear to respond to the pressure of growth. Çelik (1986) stated that after the construction boom following the 1838 Treaty, it obviously became a privilege to live in Pera.

The rapid social and economical change during $19^{\text {th }}$ century affected the cities and forced them to change. The modernization attempts demanded by the Sultan were communicated through architectural and administrative regulations (Demirakın 2015, 2). In addition to this, natural disasters in Pera during of $19^{\text {th }}$ century demanded a change in building preferences. There was limited land for new constructions at this developing part of the city and it needed to be wisely used.

All these factors triggered a typology for residential use; the single family house. In Pera, single family houses were widely built until the end of $19^{\text {th }}$ century, when higher apartment buildings which could accommodate more families on each floor gradually took over this building typology.

This study aims at defining this dwelling typology in its period. It will try to make an evaluation by examining Arapoglu Mansion, one of the few existing single family houses in the area, wih definitions of lifestyle in similar houses in written documents. It will then try to analyse if spatial changes affected family life and if domestic space was adopted to the changing social life.

\section{The transformation of the Ottoman Capital: Istanbul and Pera in $19^{\text {th }}$ century}

As the capital of Byzantine and Ottoman Empire, Istanbul has always played a vital role in the urban history. The city has been a subject of interest and desire, related with its spectacular geographical setting. Being one of the most populated cities in the world, even at the turn of $20^{\text {th }}$ century, it hosted people from different ethnic and religious backgrounds. A population of 
approximately 100.000 people came to Istanbul to get advantage of the emerging economical rights for tradesmen (Çelik 1986, 47). The motives of the rapid increase in population during $19^{\text {th }}$ century (Buluttekin 2014) was dependent on various reasons.

According to Aygen $(2007,94)$ the Empire was in search of "locating itself culturally within the frame of the post-Enlightenment European policies". Triggered by the new economical systems and institutions introduced, Istanbul witnessed rapid social and physical transformations throughout $19^{\text {th }}$ century. Most of the regulations are products of the Tanzimat Edict of 1839 . Çelik $(1986,5)$ states that the transformation of the urban space affected the society in such a way that they developed mixed feelings of anxiety, expectation and desire. The desire Çelik defines here, was for being part of the emerging lifestyle in the new neighbourhoods of İstanbul.

The development of the two already existing districts of Istanbul, located next to eachother, Galata and Pera made a peak in $19^{\text {th }}$ century. Pera outgrew after 1850 's as a part extending from Galata and towards the end of $19^{\text {th }}$ century became the showcase of westernization. In $19^{\text {th }}$ century and at the beginning of $20^{\text {th }}$ century, there was a mixture of non-muslim identities residing and running businesses in Pera such as Greeks, Armenians, Jewish people and Levantines. It is known that these minority groups being closer to Europe in terms of economical activities, religion and life style, helped stabilize the westernization efforts and introduced their own habits, as well as living tastes. Batur (1996) mentions the Levantines and the minority communities in the region who lived an elitist way of life, went to theatres, coffee houses and hotels and thus, contributed to the development of the district. When the Sultan moved to the new palace in Beşiktaş in 1856 leaving his palace at the Historical Peninsula, the high-status bureaucrats who served the Sultan wanted to reside close to the palace and found Pera as a good location to settle (Çelik 1986, 47; Batur 1996). Eldem $(1999,25)$ has a critical reminder at this point stating that there lived also the "modest employees and shopkeepers, a petty-burgeoisie and a near-proletariat" on the secondary smaller streets which lacked the attractiveness of Grand Rue de Pera (or Cadde-i Kebir), where all the big scale commerce and cultural activities took place. Pera, especially with its main axis, Grand Rue de Pera, architecturally reflected a western taste, as well. It was a place to stroll around and gaze at shop windows, enjoy the cafes and restaurants and although restricted to muslim women to some extend, was also a place to be seen in the public sphere (Batur 1996; Akın 1998).

In the aftermaths of two fires (1831 and 1870), which gave big hazard to the timber architecture in the region, masonry constructions had started to be favored. Building regulations also demanded restrictions in building materials, enlargement of roads and introduced fire walls between two buildings (Cezar 1991).

In the historical peninsula, the urban development projects after the fire disasters are regarded as "patchy" because they were merely implemented in the fire disturbed areas. However, in Pera, these were planned zones and so as to apply the plans a specific municipality (the Sixth department) was founded, which eventually acted as a model for the whole city of İstanbul (Çelik 1986, 79; Akın 1998). The street fabric and the structural features have undergone certain changes as a result of planning activities of the Sixth Department of Municipality (Batur 1996). The works undertaken by the municipality opened the way to new residential patterns, which would spread the area and further to different parts of the city towards the end of $19^{\text {th }}$ century. Among the buildings constructed at this period, there were new typologies introduced to urban life such as hotels, department stores, passages, schools for the non-muslim community, banks, theaters, restaurants and cafes (Çelik 1986; Cezar 1991; Akın 1998, 171). At the end of $20^{\text {th }}$ century the residents had already become mobile with the introduction of new vehicles. In 1874 the underground system called Tünel (the Tunnel) connected Grand Rue de Pera with the lower part of the city, whereas in 1913, electrical streetcar started its journey along Grand Rue de Pera. 
Pera and surroundings kept its priority as an urban centre throughout $19^{\text {th }}$ century until around 1914's. With the start of World War I, the social life started to fade away, and so the authentic atmosphere of the district (Akın 1998, 145).

\section{Changing family structure and relations}

The structure, function and formation of the family are closely related to the historical and social developments. It wouldn't be appropriate to formulate generic explanations on the Ottoman family structure through the wide geography and long-lasting establishment of the Empire. At the beginning of $19^{\text {th }}$ century and in early $20^{\text {th }}$ century, Istanbul had a colorful, dynamic and varied social structure. Lifestyles and structures of the families in the capital are known to have had different characteristics than those in countryside. There was a diverse social environment with the contributions of non-Muslim minority groups, Levantine and foreign inhabitants residing in the city (Duben \& Behar 1991).

A significant number of studies on the $19^{\text {th }}$ century Ottoman family focuses on the impacts of Tanzimat Reforms on issues like marriage, divorce, change in male-female emotional relationships. However, there has been limited research on the mutual constructive relationship of the changing family life and space. As the Empire got closer to Europe at the beginning of $19^{\text {th }}$ century, Western thought started to influence social life to some extend, and some social groups (especially the upper class bureaucrat and non-Muslim families) could adopt themselves to the new circumstances, while some could not adopt at the same speed, and some others adopted new thoughts to the current traditional style (Duben \& Behar 1991).

Regarding this social change, a new type of people has emerged in the description of historians: a new social stratum with new tastes ranging from fashion to daily life, with different consumption patterns, such as learning foreign languages and playing instruments in their houses (Ortaylı 1991). The famous author of the period, Y. K. Karaosmanoğlu (1922/2017, 17), describes the female character in "The Rented Mansion" as:

Seniha was always similar to the latest fashion newspapers. Fresh, thin and stealing body, such as silkworms are in a permanent metamorphism. The books she enjoyed most were Gyp's novels, new theater plays, and Paris's humorous newspapers. Gyp had been a second mother to her, a second governess. In the novels of this writer, freestyle, half-boy, halffemale young girls are the models on which they take their souls. It can be said that every day from morning till evening, she practices applying these young girl types to her life.

During the westernization period in $19^{\text {th }}$ century, the characteristics of social and family life of Western culture were easily embraced by the elite in the Empire and the formation of the family had transformed itself by time. It is observed that the extended families became nuclear families, each of which lived seperately in one house. According to 1907 data, 40 percent of the households in Istanbul was Muslim and 34 percent of Muslim households consisted of nuclear families. The average number of family members was 3.6. The same data shows that 60 percent of Muslim households contained extended family, including unmarried, widow or relatives (Duben \& Behar 1991).

Today there are still limited studies to fully understand the daily life and social patterns of Ottoman family life and the members' desires. However, expectations and passions about life can be traced in period novels, diaries and published mémoires (Duhani 1982). Many of the novel characters expose their desire to live in a modern apartment in a fancy district of the city, instead of a traditional Ottoman house in the historical district. Furthermore, it is reflected in some novels that certain districts such as Pera and Galata became more popular and had 
relatively modern urban infrastructure compared to other parts of the city. In the novels, it is easy to feel the admiration towards a new life style or the pride of being part of a modern lifestyle, living in modern residences.

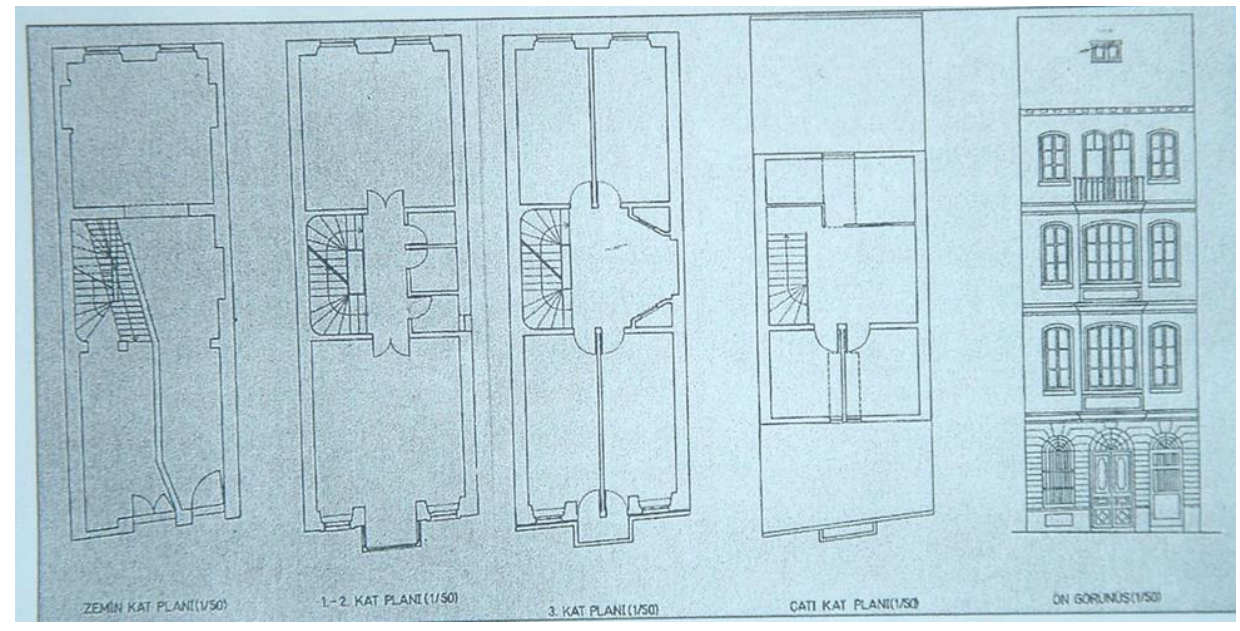

Fig. 2 Plan of a single family house studied by Enlil (1999)

\section{A new architectural typology: the single family house}

As Aktuna (2003) suggests, "the dissolution of extended families increased the demand for smaller residential units". Changes in community and family life affected the conventional views on privacy, which has by time gradually dissolved (Yücel 1998, 303). This can also be witnessed from the architecture of the period.

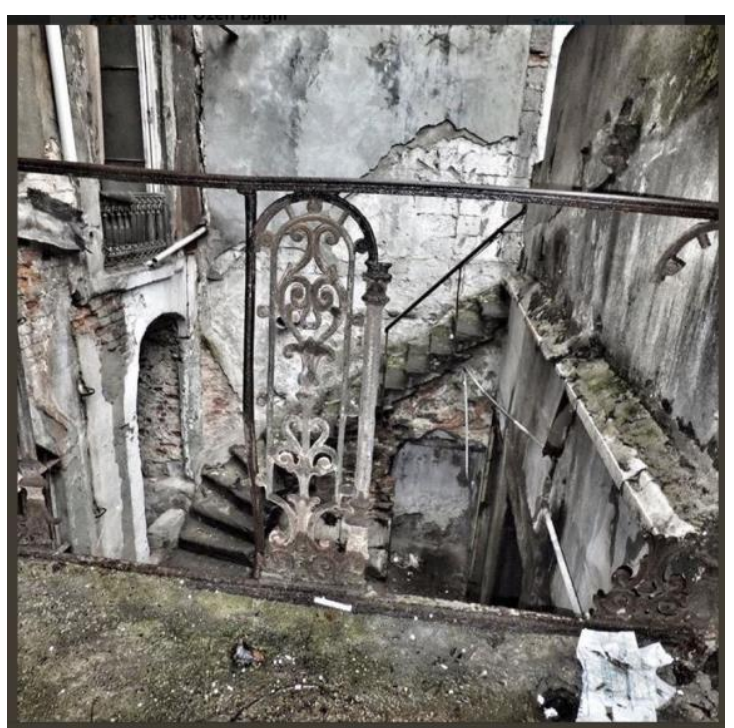

Fig. 3 Arapoğlu Mansion and a partial view of its backyard from the first floor (Photo: Özen Mimarlık Mühendislik Ltd. archive, 2014)

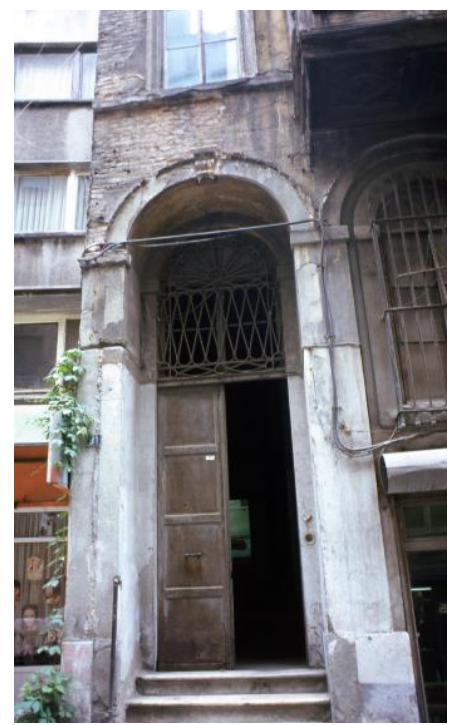

Fig. 4 The monumental entrance of Arapoğlu Mansion (Photo: B. S. Yalçın, 2004)

Based on the written documents and engravings depicting Pera and surroundings, the residences in the region were generally multi-storey mansions housing one family, until the second half of $19^{\text {th }}$ century. Some of these houses used to be big mansions with gardens located along Grand Rue de Pera and Tepebaşı (Petits-Champs) (Cezar 1971, 54 and 109). World-famous Greek banker Zarifi's house, Glavany's house and Caro's house along Petits-Champs, piano-maker Alexandre Commendinger's house along Polonya Street and Azaryan Efendi's house at the 
corner of Tiyatro Street are some of these mansions to mention (Duhani 1982).

During the early period of the transformation of the traditional "street-yard-sofa-rooms" order in $19^{\text {th }}$ century, emerged a new residence type in Pera.

These houses are regarded as transition cases from traditional houses to apartment type residences in the region which was going to appear some years later (Cezar 1971). The new dwelling type, known as "the single-family house" started to be widely used in Pera and in new neighbourhoods developing in other parts of the city. These row houses had entrances directly from the street into the inner space. They were generally two to four storey modest buildings, built on narrow frontage lots (Fig. 2). Located on densely populated, narrow roads, they didn't offer much outer space. The front and back rooms were linked to eachother generally by a narrow sofa.

They usually had a projecting bay window/jetty at the front, which resembled the traditonal houses in Istanbul. Durudoğan (1998) states that the reason to build these projecting bay windows was usually to expand the limits of the small room looking over the street and to have more space for the most important room of the house. They were generally placed in the middle of the room and one or two storeys high. Some of them ended up on the top with a small balcony, while some others with a roof. Addition of such a feature from traditional Ottoman residential architecture can be regarded as an unconscious approach to bring western and Ottoman architecture closer.

Enlil (1999) suggests that the regularity of these houses were the result of a series of building regulations passed in the $19^{\text {th }}$ century as part of the modernization agenda, which "sought to unify the urban fabric" aganist the threat of another devastating fire disaster. These regulations demanded the use of masonry structure and certain dimensions. The way that they defined a solution for Pera is what made the residential architecture unique among earlier single family houses.

The general layout of the plan was rooms on both side of the building with a small sofa (sometimes a narrow corridor) connecting these spaces. These row houses usually had one room at the front as big as the width of the lot and two rooms at the back. There were no gardens in the single family houses of Pera, neither at the front nor at the back. The garden of the traditional Ottoman house had eventually disappeared and thus, instead of gardens these houses had small backyards as service spaces (Fig. 3). The two facades of houses were facing the street and the backyard. The main gate of the neoclassically decorated facades were monumental and usually emphasized the entrance (Fig. 4). The building materials were usually brick, plastered from outside and timber beams that carried the floors/ceilings (Ertuğrul 2009, 304). Enlil (1999, 309) suggests that the reason why many of these row houses in Pera survived is that masonry structures have been more persistent against atmospheric effects and fire disasters, which easily demolished timber houses of the same scale at different parts of Istanbul (Fig. 5).

Like Enlil (1999, 308-309) who suggests that people living in these houses might have abandoned some of their existing living habits to adopt themselves to this new housing type, Öncel (2010) uses the memories of Yordanidou from a period novel to understand and interpret the lifestyle in these multi-storey family dwellings. Loksandra, in Yordanidou's novel, was an Ottoman lady from Greek origins who lived her youth in Bakirkoy, another district on the suburban area of the city. She was probably raised in a timber house (a konak) surrounded by a garden with fruit trees. In her elderly times, she had to move to a single family house in Pera. In her writings, she declares that she found living in this house difficult, because the house hadn't let enough sunlight in. 

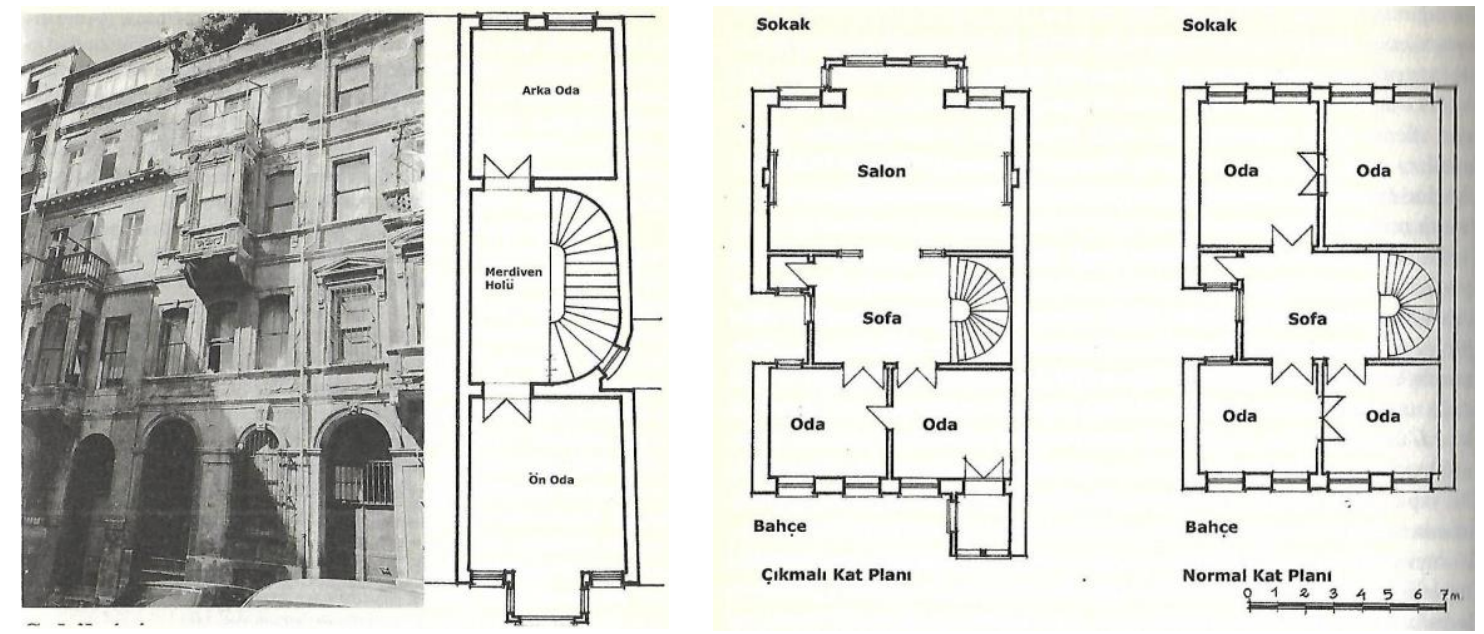

Fig. 5 Plans of similar houses (Source: Öncel, 2010)

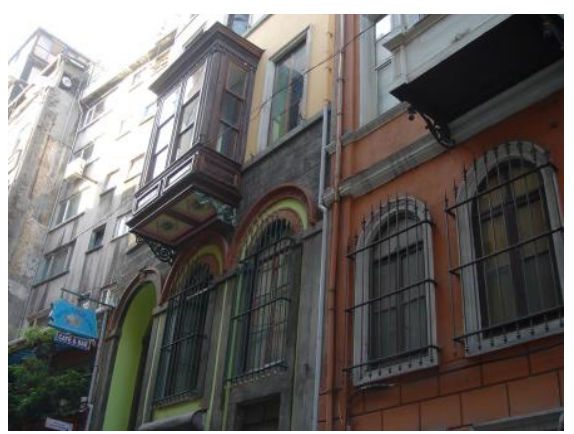

Fig. 6 The current state of the building (Photo: B. S. Coşkun, 2012)

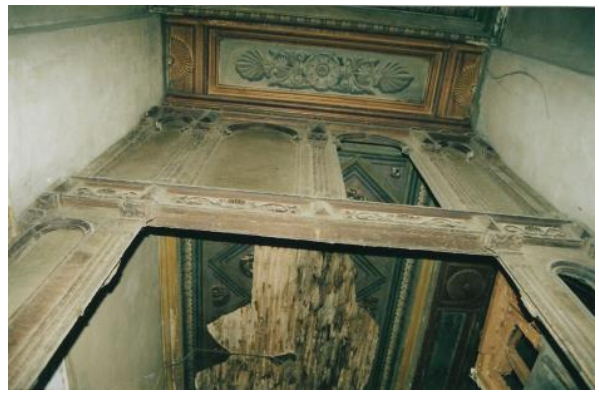

Fig. 8 Detail from the decorated ceiling on ground floor (Photo: B. S. Yalçın, 2003)

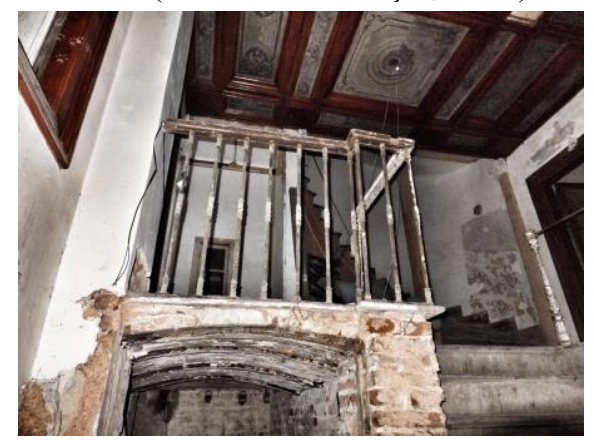

Fig. 9 Decoration of one of the rooms in the mansion (Photo: B. S. Yalçın, 2003)

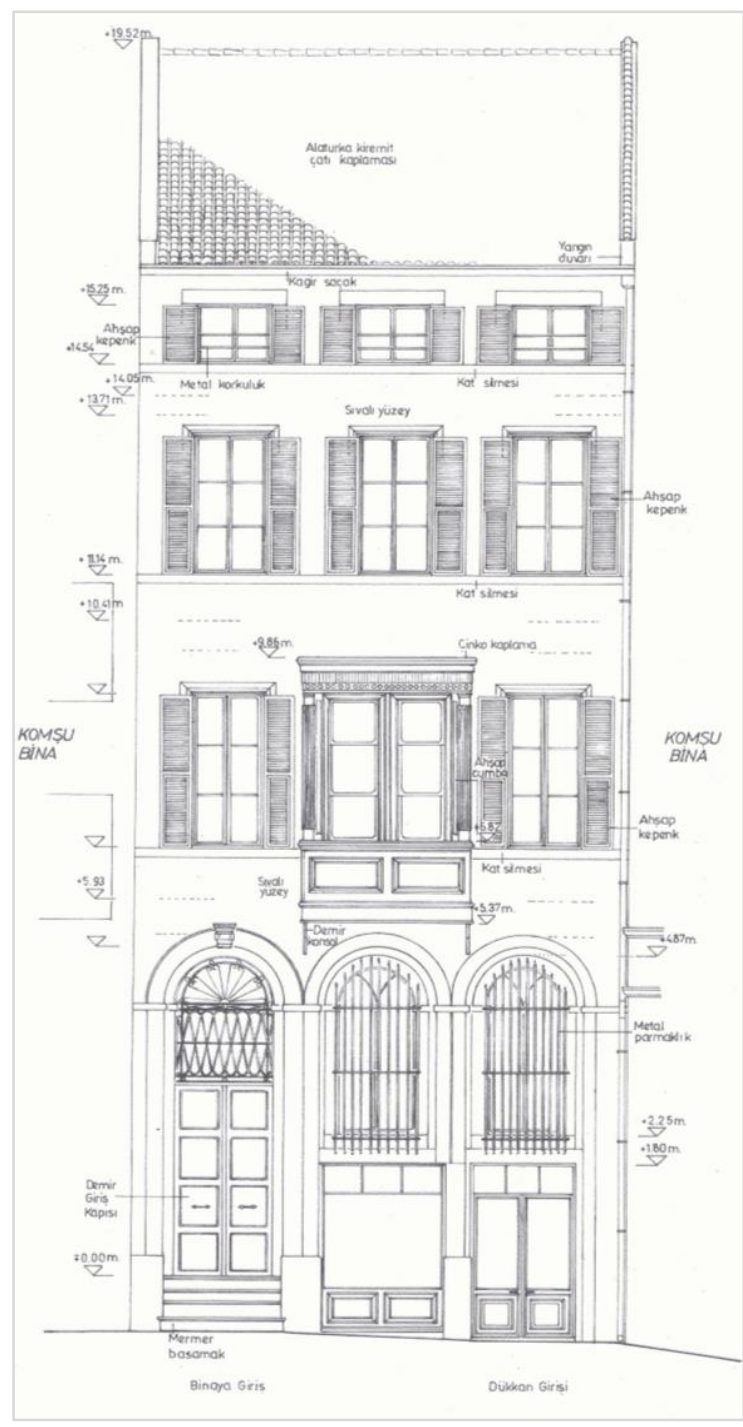

Fig. 7 The reconstruction drawing of the facade of Arapoğlu Mansion, Drawing by B. S. Yalçın, 2003 
Another description of such a house comes from Yücel's $(1998,34)$ study of row houses. A house in 1930 is depicted as a house with a stone-paved backyard and a Turkish bath and a launderette located at this backyard. The house had three rooms on each floor, two facing the main street and one facing the small backyard. Yücel states that the street consisted of many similar houses which were all built by Greek builders. The top floor in this house used to belong to the maid of the house and had a considerably lower ceiling level. This is typical for western traditions, however didn't exist in Ottoman architecture, in which the upper floors actually were more valuable (Enlil 1999). Thus, the upper floor's being used as the maid's rooms must be an adoption from western cultures.

Today there are stil few examples of single family houses in Pera (today Beyoğlu) which have been converted into different uses. Arapoğlu Mansion is among these few houses, which have survived our time. After being used as a family residence, it was transformed into a multifamily residential building, and then into various workshops. Its architecture still highlights the features of the domestic life which went on during $19^{\text {th }}$ century.

\section{Arapoğlu Mansion in Pera}

Arapoglu Mansion (No. 31 on the street) stands on the former Brousse street (today named as Sadri Alışık street), which is located perpendicular to Grand Rue de Pera, linking the upper part of Beyoğlu to the lower part, Çukurcuma, another residential area. Brousse (or latter name as Ahududu) Street was one of the secondary streets that lacked the attractiveness of the main axis of Pera, as explained above referring to Eldem $(1999,25)$, it used to be one of the main streets of secondary importance and is stil a busy one, today.

As it is known that that the fire in 1870 gave much hazard, especially to the left part of the area between Taksim and Galatasaray, where Arapoglu Mansion is located, the building must have been built right after this disaster. The most recent owners of the house that can be identified by the information given by the current users (tenants) were a Ottoman-Greek origined couple, Dimitri and Zoi Arapoğlu. Today the building belongs to a minority trust (Balıklı Greek Hospital Foundation) and has recently been rented out to a company that uses the bulding as a hotel after its extensive restoration in 2017 (Fig. 6).

The building is defined with the letter $\mathrm{H}$ on the 1905 detailed fire insurance street map prepared by Charles E. Goad Ltd.. The letter H stands for the word "habitation", a synonym for single family houses. Several people could be traced from records, who lived and worked on Brousse street between 1883 -1966 in Annuarie Oriental (1883). According to these records, in 1870 's when the house must have been built, there was no commercial activity on the street. The street must have been hosting merely residential buildings, which belonged to a considerably modest group of people, compared to the owners of big scale mansions on the main avenues.

Although it is not possible to identify if he was the first owner of the house, Alfred Caporal's name is captured in Annuarie Oriental (1883) record as the person living in Arapoglu Mansion. He was known to be a banker working in Galata and in newspaper records of 1880's his daughter's name was mentioned for her marriage celebration, which tells us that Caporals might have lived in this house as a family, at least until 1889 when Caporal's daughter got married. This strengthens the idea that the house used to be the home of one single family, in this case the Caporal's family.

Arapoğlu Mansion changed owners several times until the building became a trust/waqf property in 1960s. According to Annuarie Oriental, following Alfred Caporal, an OttomanGreek widow, Madame Netti took over the ownership of the house.

She used to run a launderette serving the neighbourhood at the backyard, of which there are 
still traces today. When Madame Netti passed away, her relatives Zoi and Konstantin Netti became the owners of the house. When Konsantin Netti moved to Athens, Zoi got married for the second time and the ownership of the house passed to Zoi and Dimitri Arapoğlu couple. The building becomes the trust's property when Dimitri Arapoğlu, who used to be working as a representative of Scandinavian Near East Agency in Istanbul (URL 1) passed away in Corfu (Greece) in 1962.

With its architectural vocabulary and decoration approach, Arapoğlu Mansion echoes the typical buildings in Pera in $19^{\text {th }}$ century. Its architectural features highlight the basic taste of its period. As a row-house it has only two facades, the entrance facade being more elaborate and decorated (Fig. 7). Arapoğlu Mansion's entrance on the ground floor has a highly decorated (Fig. 8) ceiling, with flowers and geometrical patterns. There are also different decoration programmes on bigger rooms located on first and second floors of the building (Fig. 9). The projecting bay window (jetty) on the first floor is structurally made of timber. It is a small reminiscence of the traditional timber houses built the same era in the city. In Pera, however, there are very few examples left from such timber jetties (Yalçın 2003) (Fig. 10). The jetty is carried by two decorated iron supports, typical of the taste of $19^{\text {th }}$ century. There are metal shutters inside this main room, as well as the rooms facing the backyard, probably to keep the building away from any fire disaster. One can understand from the hinges and metal pieces stil existing on the facades that there used to be wooden shutters to keep the light out of the house, but none of these have survived to $21^{\text {st }}$ century.

Architecturally Arapoğlu Mansion's plans carry the characteristics of a $19^{\text {th }}$ century timber house seen at other new neighbourhoods at different parts of the city. This is the evidence that although the materials used and the facade decoration style of the house changed in Pera, the way the spaces were organized stayed unchanged. The house has a plan with two rooms at the front and two at the back (Fig. 11). The rooms are connected to each other linearly with a sofa, and vertically with a still imposing, well-preserved staircase, which is lit in this case from above with a glass roof (Fig. 12). The glass part of the roof is visible on Goad insurance map (Fig. 13).

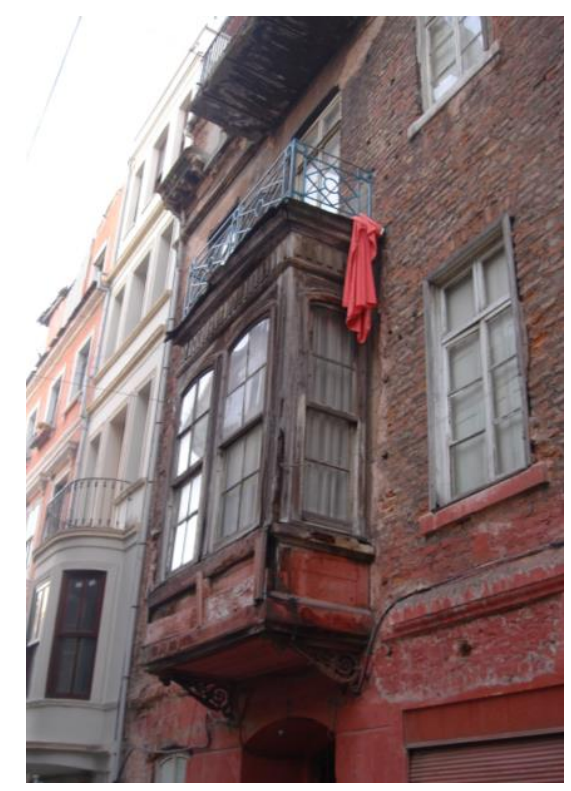

Fig. 10 A timber constructed jetty from a house at Serdar-1 Ekrem street, Galata (Photo: B. S. Coşkun 2015)

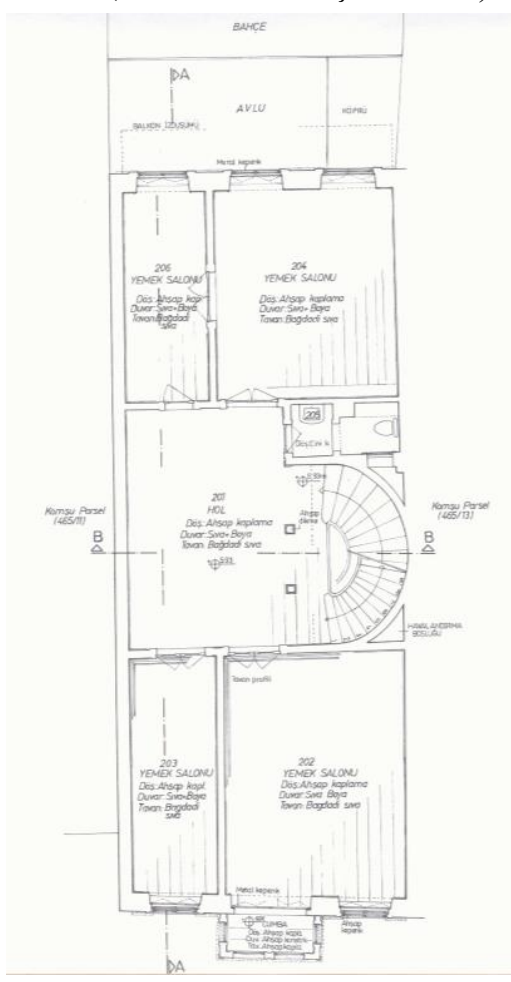

Fig. 11 The layout of one typical floor plan, second floor (Drawing by B. S. Yalçın 2003) 
There are WCs on each floor, tucked in a corner of the sofa, which can be later period additions. The kitchen is on one corner of the backyard, sharing the backyard with the launderette. Kitchen's being located outside the house is often seen at traditional timber houses, so can be regarded as a typical solution for residential buildings in the whole city.

The less decorated back facade of the building can partially be observed from Tel Street. On this facade, the most attractive feature is the balcony on the third floor with a decorated railing, which actually gives the $19^{\text {th }}$ century character to the building. The balcony is an architectural feature that reminds us the westernized style of the house. Such a balcony never existed in a similar Muslim house due to privacy issues.

Urban houses like Arapoglu used to be 3-4 storey buildings with entrances directly from the street. They sometimes had shops like in the case of Arapoğlu, which differed them from the stereotype house plans of a Muslim family. The place for a shop on the ground/street level was pobably not there, when the building was first built. However, Öncel $(2010,129)$ finds evidence on shops as part of the ground floor of the family houses, with vaulted ceilings, which is the case in Arapoğlu Mansion.

Öğrenci (1998) states in her thesis that as the house gets into a closer relationship with the street, the role of the garden becomes less important and the space left for the garden becomes smaller. This is just the same case in

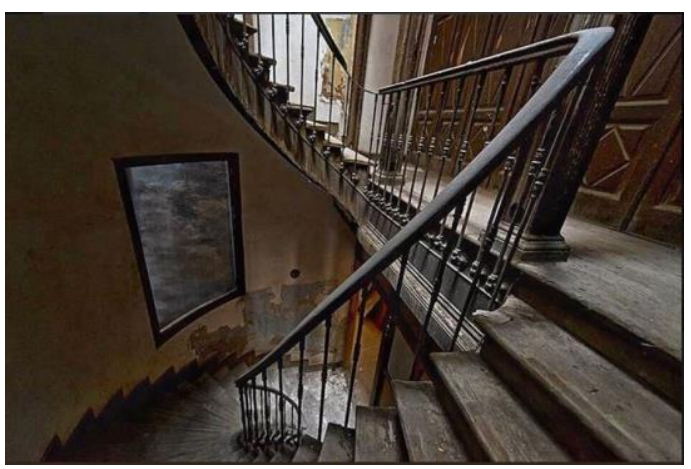

Fig. 12 The staircase, (Photo: Teri Erbeş 2013)

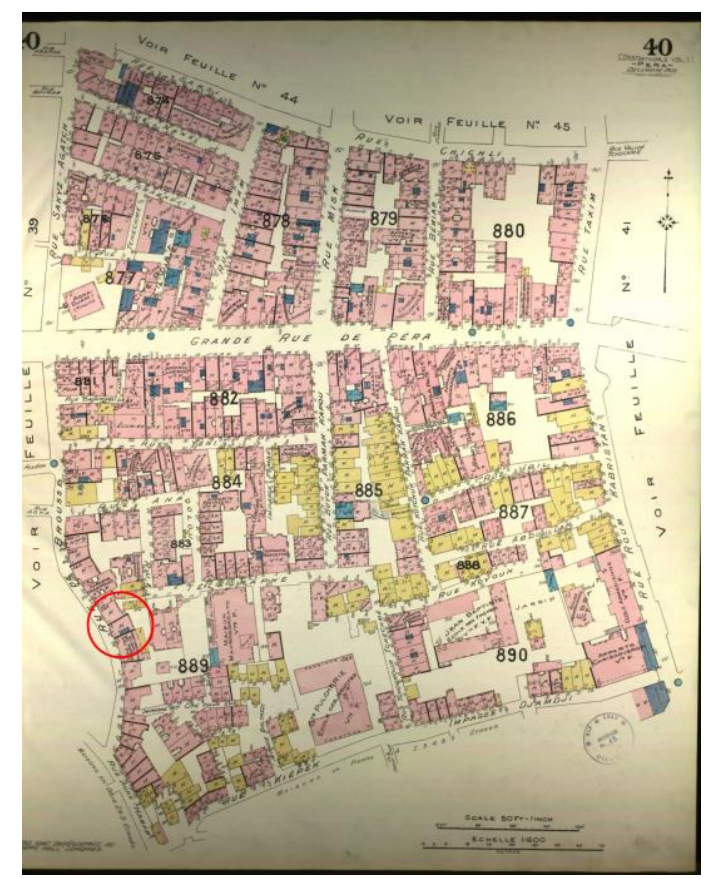

Fig. 13 The Brousse street where Arapoğlu Mansion is located, 1905 Goad map (L'Institut Français d'Études Anatoliennes in Istanbul) Arapoğlu Mansion, too. There is a small backyard and the original users might have been using the top of the laundrette and the kitchen area as a small terrace, to dry their laundry.

As a result, Arapoğlu Mansion on Brousse Street was a typical $19^{\text {th }}$ century single family house, a rowhouse with two facades which served several non-muslim Ottoman families during its most favored times. It held the typical characteristics of this typology and the way the spaces were organized gives clues about the preferences of its users, how they adopted themselves in spatial dimension to the changes of the period which they were a part of and the emerging building traditions demanded by the regulations of the Ottoman authorities during $19^{\text {th }}$ cenury. Arapoğlu Mansion's architecture reflects the changing lifestyles and desires of $19^{\text {th }}$ century in this developing part of the city.

\section{Conclusion}

Pera gradually became an important component of Istanbul starting from early $19^{\text {th }}$ century. A new cultural atmosphere, partially imported from western countries and blended with already existing traditions of the non-muslim minorities, emerged in Pera. Although Grand Rue de Pera 
has scholarly been much studied, Pera is historically and architecturally much more than this. The residential areas surrounding the narrow streets opening to the main axis consist of different typologies of houses, among which there is the single family house as an early example. These row houses with narrow facades and entrances directly facing the main street are considered as variations of existing residential building traditions in the city and are regarded as early models that prepared the emergence of apartment buildings which are the main architectural heritage of today's Beyoğlu/ Pera. Belonging basically to the petit bourgeoisie of the Empire, their existence can be explained within the conditions that prepared the coming out of such a class (Batur et al. 1979; Enlil 1999).

This study introduced one of the still existing single-family houses. Due to various alterations in time, the original state of the building is not easily recognizable today. The house has recently been restored and converted into a hotel. However, the plans, the organization of rooms and the decoration of the inner space reflect the characteristics of this typology.

Arapoğlu Mansion, as a case, together with written documents on domestic life in $19^{\text {th }}$ century, can help the readers develop a better understanding of the family life in Pera. It can be suggested that although they didn't offer much outer space and green, these houses were quite convenient, and fancied by their owners. However, in time, each storey was converted into an individual apartment and then rented out. Some were demolished to give way to new constructions. With the demand of the rapid increase in population at the beginning of $20^{\text {th }}$ century, the owners felt themselves forced to move to new dwellings and this typology has in time been totally abandoned.

\section{Author's Note}

The information of the people who used to live in Arapoğlu Mansion is gathered from the unpublished archival study conducted by historian Saadet Özen and architect Seda Özen Bilgili, whose architectural practice was responsible of the restoration of Arapoğlu Mansion and the conversion of the building into a hotel.

This article has been studied through the data gathered from the master thesis dissertation of the corresponding author, Assoc. Prof. Dr. B. Selcen Coşkun; (B. S. Yalçın, 2003. Beyoğlu Ahududu Sokağı ve Sokakta Yer Alan 31 No'lu Arapoğlu Evinin Korunması İçin Öneriler. Yayımlanmamış Yüksek Lisans Tezi. YTÜ, İstanbul). 


\section{REFERENCES}

Akın N. (1998). 19. Yüzyllın İkinci Yarısında Galata ve Pera. İstanbul 1998.

Aktuna Z. (2003). Re-Reading The Social Context of Apartment Block, Development in Istanbul: 1889-1922. Yayımlanmamış Yüksek Lisans Tezi. ODTÜ, Ankara 2003.

Annuarie Oriental (1883). Salt Araştırma. İstanbul.

Aygen Z. (2007) "From A Ship Sailing East with its Voyagers Travelling West Architectural Saints, City Fathers and Design Patrons in the Late Ottoman Empire". J Design Hist 20/2 (2007) 93108.

Batur A. (1996). "Galata and Pera 1, A Short History, Urban Development Architecture and Today". ARI, The Bulletin of the Istanbul Technical University 55/1 (1996) 1-10.

Batur A., Yücel A. \& Fersan N. (1979). “İstanbul'da 19. yüzy1l Sira evleri”. ODTÜ Mimarlık Fakültesi Dergisi 5/2 (1979) 185-203.

Buluttekin M. B. (2014). "A City Right at the Core of Global, Political, Economical and Social Changes of the $19^{\text {th }}$ Century: Istanbul". Dicle Üniversitesi Hukuk Fakültesi Dergisi 19 (2014) 30-31.

Cezar M. (1971). Sanatta Batı'ya Açılış ve Osman Hamdi. İstanbul 1971.

Cezar M. (1991). “19. yüzy1lda Beyoğlu neden ve nasıl değişti?”. Proceedings Book of XI ${ }^{\text {th }}$ Turkish History Congress (5-9 September 1990). Vol. VI (1991) 2674-2690.

Çelik Z. (1986). The Remaking of Istanbul: Portrait of an Ottoman City in the Nineteenth Century. Washington 1986.

Demirakin N. I. (2015). The City as a Reflecting Mirror: Being an Urbanite in the $19^{\text {th }}$ Century Ottoman Empire. Yayımlanmamış Doktora Tezi. Bilkent Üniversitesi, 2015.

Duben A. \& Behar C. (1991). Istanbul Households: Marriage, Family and Fertility1880-1940. Cambridge 1991.

Duhani S. (1982). Eski İnsanlar Eski Evler-19.Yüzyılda Beyoğlu'nun Sosyal Topoğrafyası. İstanbul 1982.

Durudoğan S. (1998). XIX. Yüzyılda Pera/Beyoğlu'nun Ekonomik, Kültürel ve Politik Yapısının Mimariye Etkileri. Yayımlanmamış Doktora Tezi. İTÜ, İstanbul, 1998.

Eldem E. (1990). "Istanbul: From Imperial to Peripheralized Capital". Eds. E. Eldem, D. Goffman \& B. A. Masters, The Ottoman City between East and West: Aleppo, Izmir, and Istanbul. Cambridge 1999.

Enlil Z. (1999). "Residential Building Traditions and the Urban Culture of Istanbul in the 19th Century". Ed. N. Akın, 7 Centuries of Ottoman Architecture "A Supra-National Heritage" (1999) 306-315. İstanbul.

Ertuğrul A. (2009). "XIX. Yüzyılda Osmanlı'da Ortaya Çıkan Farklı Yapı Tipleri”. Türkiye Araştırmaları Literatür Dergisi 7/13 (2009) 293-312.

Karaosmanoğlu Y. K. (1922/2017). Kiralık Konak. İstanbul 1922/2017.

Ortaylı İ. (1991). "Osmanlı Toplumunda Ailenin Yeri”. Türk Aile Ansiklopedisi 1 (1991) 74-79. Ankara.

Öncel D. (2010). Apartman: Galata'da Yeni Bir Konut Tipi. İstanbul 2010.

Öğrenci P. (1998). 19. Yüzyıl Özgün Konut Tipleri Bağlamında Sarıca Ailesi Yapıları, Mimar C. Pappas ve Arif Paşa Apartmanı. Yayımlanmamış Yüksek Lisans Tezi. YTÜ, İstanbul 1998.

Tümertekin E. (2014). Insan ve Mekan. İstanbul 2014.

Yalçın B. S. (2003). Beyoğlu Ahududu Sokağı ve Sokakta Yer Alan 31 No'lu Arapoğlu Evinin Korunması İçin Öneriler. Yayımlanmamış Yüksek Lisans Tezi. YTÜ, İstanbul 2003.

Yücel A. (1998). "Typology of Urban Housing in $19^{\text {th }}$ Century Istanbul". Ed. Y. Sey, Housing and Settlement in Anatolia: A Historical Perspective (1998) 298-312. İstanbul.

URL 1: https://twitter.com/seda_ozen/status/772013579822329860, Access Date: 5.10.2019. 